\title{
DIGESTION KINETICS, PERFORMANCE AND CARCASS CHARACTERISTICS OF SHEEP AS AFFECTED BY FEEDING FREQUENCY
}

\author{
H. T. Taie
}

Department of Animal Production, Faculty of Agriculture, University of Menofiya

\section{SUMMARY}

A series of experiments was carried out to study the effect of feeding frequency on ruminal fermentation, digestion kinetics, performance and carcass information in sheep. The experimental ration was fed under three feeding frequencies at the same total feed intake (one, two and three times a day). Time of feed offering was at 8:00 h (once), 8:00 and 12:00 h (twice) and 8:00, 12:00 and 16:00 h (three times). Three separate trials were carried out on sheep; a metabolic trial with three rams; a digestion kinetic trial with three ruminal fistulated sheep and a performance and slaughter trial with twenty-one lambs with initial body weight $31.0 \mathrm{~kg}$. They were distributed into three similar groups.

Results indicated that: apparent digestibility of CP, DM and CF was highest for $2 X$ followed by $3 X$ daily. Values of TDN and DCP were improved with increased feeding frequency. Nitrogen retention was increased; percentage of nitrogen retainted: nitrogen intake or nitrogen retainted: nitrogen digested followed the same pattern. Diurnal variation in ruminal $\mathrm{pH}$ was less dramatic with sheep fed $2 \mathrm{X}$ and $3 \mathrm{X}$ daily. $\mathrm{A}$ sharp increase in VFA production was detected up to $3 \mathrm{~h}$ post-feeding then steadily increased at $6-7 \mathrm{~h}$ post feeding for $2 \mathrm{X}$ and $3 \mathrm{X}$ daily. Further increase was found at 10 $\mathrm{h}$ post-feeding for $3 X$ daily. The highest value of $\mathrm{NH}_{3}-\mathrm{N}$ was $22.75 \mathrm{mg} / \mathrm{dl}$ at $3 \mathrm{~h}$ for $1 \mathrm{X}$ daily, 20 and $21 \mathrm{mg} / \mathrm{dl}$ for $2 \mathrm{X}$ at 2 and $6 \mathrm{~h}$.; the maximum values were 18.2, 22.5 and $21 \mathrm{mg} / \mathrm{dl}$ for $3 X$ at 1,6 and $9 \mathrm{~h}$ post-feeding. Digesta rumen retention time (RRT) was linearly increased as feed frequency increased. Digesta passage rate $\left(R_{p}\right)$ followed the opposite trend and linearly decreased. However, rate of digestion $\left(R_{d}\right)$, was equal at all treatments being $6.0 \% \mathrm{~h}^{-1}$. Dry matter digested within the rumen as well as fractional DMD increased. However, digestion in the lower digestive tract decreased as feeding frequency increased. Both average daily gain and feed efficiency were improved with increasing feeding frequency.

Keywords: Sheep, feeding frequency, ruminal fermentation, digesta kinetics.

\section{INTRODUCTION}

Many investigators (Burt and Dunton, 1967; Stanley and Morita, 1967; Smith et al 1978) have reported that feed intake is not stimulated by offering mixing rations more than once daily. Whole tract nutrient digestion also is not affected (Honing et al.,

Issued by The Egyptian Society of Animal Production 
1976; Robinson and Sniffen, 1985). However, increasing frequency of feeding will lead to less fluctuation of ruminal characteristics and stabilize diurnal rumen fermentation pattern (Jensen and Walstrup, 1977; Nocek and Braund, 1985; Nocek 1987). This may theoretically increase efficiency of nutrient digestion in the rumen (Johnson, 1976; Baldwin and Denham, 1979; Ulyatt et al., 1984). This will also enhance fiber digestibility and maximize microbial yield (Nocek, 1992) which may lead to a positive response in the production efficiency (Gibson, 1981). The present study was undertaken to investigate the effect of more frequent feeding of the same ration on digestion kinetics, performance and carcass characteristics of sheep.

\section{MATERIALS AND METHODS}

The following experiments were carried out in the Experimental Farm of Department of Animal Production, Faculty of Agriculture, Menofiya Univ.

\section{Exp.l .Digestion and Nitrogen balance trial:}

Three Ossimi rams with an average body weight of $50 \pm 1 \mathrm{~kg}$ were used in a digestion and $N$ balance trial in a $3 \times 3$ Latin square design to test the experimental treatments that were feeding frequencies. i.e., once, twice and three times per day at the same daily feed intake from the same ration. Time of feed offering was at $8: 00 \mathrm{~h}$ (once), 8:00 and 12:00 $\mathrm{h}$ (twice) and 8:00, 12:00 and 16:00 h (three times). The ration offered was formulated to contain $70 \%$ concentrate feed mixture plus $30 \%$ roughage (berseem hay and chopped wheat straw at $1: 1$ ratio on DM basis). The chemical composition of feed ingredients as well as the experimental diet are presented in Table (1). Animals were placed in metabolic cages as described by Maynard et al., (1979) and were fed their maintenance requriments recommended by NRC (1975). A preliminary period of 4 weeks was allowed followed by a 7-day collection period for each Latin square interval. Every morning diet was offered according to the above mentioned systems. Water was available ad lib. Feed and fecal samples were dried at $70^{\circ} \mathrm{C}$ and ground through a Wiley mill (2-mm screen) before laboratory analysis. During the collection period, urine was collected and measured daily and a $10 \%$ aliquot was composited and refrigerated till analysis for nitrogen. Thirty $\mathrm{ml}$. of $50 \%(\mathrm{VN}) \mathrm{H}_{2} \mathrm{SO}_{4}$ was added to the urine vessels daily to retard ammonia nitrogen $\left(\mathrm{NH}_{3}-\mathrm{N}\right)$ loss. Analysis of feedstuffs and feces was carried out according to A.O.A.C. (1980). Total urinary- $N$ was estimated by using the Markham micro-distillation apparatus (Markham, 1942).

Exp. II. Digestion kinetics and rumen fermentation:

Three Ossimi rams (mean weight $45 \mathrm{~kg}$ ) were fitted with rumen fistulae. Animals were kept on the above mentioned feeding regimen in a Latin square design. Animals were adapted to the diet for 30 days. In order to determine the microbial activity, rumen contents were sampled through the fistula on the last two days from each experimental period immediately before feeding, then for $12 \mathrm{~h}$ post-feeding at $1 \mathrm{hr}$ intervals: Rumen contents were strained through two layers of cheese cloth. Ruminal $\mathrm{pH}$ was recorded immediately using a $\mathrm{pH}$-meter with a glass electrode followed by

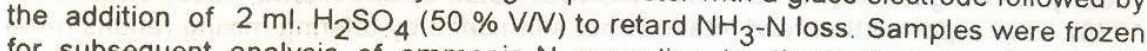
for subsequent analysis of ammonia- $\mathrm{N}$ according to the method described by AlRabbat et al., (1971)and total volatile fatty acids (VFA) as described by (Warner, 
1964). Ruminal rate of DM digestion was measured using the technique of Mehrez and Orskov, (1977). Rates of digestion were calculated as regressions of natural logarithmic transformation of digestible DM remaining at $6,12,24,36$ and $72 \mathrm{hr}$ of fermentation. The potentially digestible fraction was that portion of feed that had disappeared in $72 \mathrm{~h}$ of exposure to ruminal fermentation. To estimate rates of DM passage and retention time, $5 \mathrm{gm}$ of $\mathrm{Cr}_{2} \mathrm{O}_{3}$ was dosed into the rumen via the rumen fistula just before the morning feeding. Rumen contents were sampled at $0,2,4,6,8$, 24, 48 and $72 \mathrm{~h}$ after dosing. Chromium was determined by atomic absorption spectroscopy as described by William ot al., (1962). Passage rate from the rumen was calculated by regression of the natural logarithm of chromium concentration on time after feeding. Average retention time of DM in the rumen was calculated as the inverse of passage rate content, $1 / K_{n}$ (Staples $\theta t$ al., 1984).

Table1. Chemical composition of different ingredients used in the experimental rations (on DM basis \%)

\begin{tabular}{lccc}
\multicolumn{1}{c}{ Item } & *FM $(\%)$ & Clover hay $(\%)$ & Wheat straw (\%) \\
\hline Organic matter, OM & 88.90 & 86.10 & 88.48 \\
Crude protein, CP & 15.80 & 13.00 & 3.00 \\
Crude fiber, CF & 10.00 & 21.20 & 34.44 \\
Ether extract, EE & 5.20 & 2.10 & 1.44 \\
Ash & 11.10 & 13.90 & 11.52 \\
N-free extract, NFE & 57.90 & 49.80 & 49.63 \\
Determined analysis of the experimental ration (on DM basis): \\
Organic matter \\
Crude protein. \\
Crude fiber. \\
Ether extract \\
NFE
\end{tabular}

- CFM, Concentrate Feed Mixtures composed of $28 \%$ soybean meal, $44 \%$ wheat bran, $19 \%$ yellow maize, $3 \%$ rice bran, $2 \%$ limestone, $1 \%$ salt and $3 \%$ molasses.

Exp. III. Performance and Slaughter information.

Twenty-one Ossimi lambs with initial body weight of $31.0 \pm 1 \mathrm{~kg}$ were used in this study to obtain the performance data and carcass information. Animals were distributed into three similar groups, seven lambs each, in a completely randomized experimental design. They were fed the experimental diet (Table 1) for 150 days experimental period. Diet was offered in the same feeding system as followed in the previous experiments. The experimental ration was formulated and offered in quaintities to supplly the recommended nutrient allowances according to Ghoneim and Raafat (1957) for growing lambs in relation to their weights and growth rates. Lambs were weighed every 14 days. Water was available ad libitum. At the end of the experimental period all lambs were slaughtered after they have been fasted for 12 $h$ before slaughtering. Hot carcass was weighed without any attached offals and then divided into left and right sides. Best ribs $(9,10$ and 11) cut was separated from the left side and weighed. The boneless meat was separately weighed and chemically analyzed to determine moisture, protein, fat and ash percentage (A.O.A.C., 1980). Data were statistically analyzed after Gill (1978). 


\section{RESULTS AND DISCUSSION}

Data in Table (2) show that feeding frequency had a significant $(P<0.05)$ effects on digestlbilitles of DM, CP, CF and EE. Values were greatest in $2 X$ group followed by $3 X$ group and being least in the $1 X$ group.

The higher nutrients digestibilities of both twice and thrice feeding system led to better nutritive values expressed as TDN and DCP. Values of TDN were $68.28,67.17$ and $64.74 \%$ for twice, thrice and once feeding system. The corresponding values for DCP were $9.74,9.56$ and $8.95 \%$. Differences were significant $(P<0.05)$.

Table2. Effect of feeding frequency on nutrient digestibility and feeding value in sheep.

\begin{tabular}{lccc}
\hline Item & \multicolumn{3}{c}{ Daily feeding frequency } \\
\cline { 2 - 4 } & once & twice & thrice \\
\hline Digestibilities \% & & & \\
Dry matter, DM & $71.65 \pm 2.15 \mathrm{a}$ & $75.2 \pm 2.72 \mathrm{~b}$ & $76.5 \pm 2.24 \mathrm{~b}$ \\
Crude protein, CP & $64.48 \pm 2.4 \mathrm{a}$ & $70.60 \pm 1.1 \mathrm{~b}$ & $68.30 \pm 1.3 \mathrm{~b}$ \\
Crude fiber, CF & $50.53 \pm 2.15 \mathrm{a}$ & $58.8 \pm 3.32 \mathrm{~b}$ & $58.25 \pm 1.19 \mathrm{~b}$ \\
Ether extract, EE & $65.00 \pm 1.4 \mathrm{a}$ & $79.50 \pm 2.72 \mathrm{~b}$ & $78.25 \pm 1.75 \mathrm{~b}$ \\
N.free extract, NFE & $76.09 \pm 1.5$ & $76.29 \pm 1.95$ & $75.00 \pm 1.51$ \\
Feeding value \% DM & & & \\
TDN & $64.74 \mathrm{a}$ & $68.28 \mathrm{~b}$ & $67.17 \mathrm{~b}$ \\
DCP & $8.95 \mathrm{a}$ & $9.74 \mathrm{~b}$ & $9.56 \mathrm{~b}$ \\
abvalues not sharing the same superscripts within the same row differ significantly $(P<0.05)$.
\end{tabular}

In order to clarify the mechanism by which digestion was improved due to more feeding frequency, ruminal fermentation and digestion kinetics were studied. Ruminal activity as affected by feeding frequency was tested by the change in $\mathrm{pH}$ value, volatile fatty acids (VFA) and $\mathrm{NH}_{3}-\mathrm{N}$ concentrations. Ruminal $\mathrm{pH}$ values were higher for all treatments before feeding, being on the average 6.7 (Fig.1), then decreased steadily to reach their lowest values at $3 \mathrm{hr}$ and then increased at $4 \mathrm{~h}$ post feeding. The $\mathrm{pH}$ values started to decline at 5-6 $\mathrm{h}$ with $2 X$ and $3 X$ treatments. Other increase of $\mathrm{pH}$ was noticed at $8 \mathrm{~h}$ post feeding for $3 X$ feeding and steadily decreased at $10 \mathrm{hr}$ for $3 X$ and then increased.

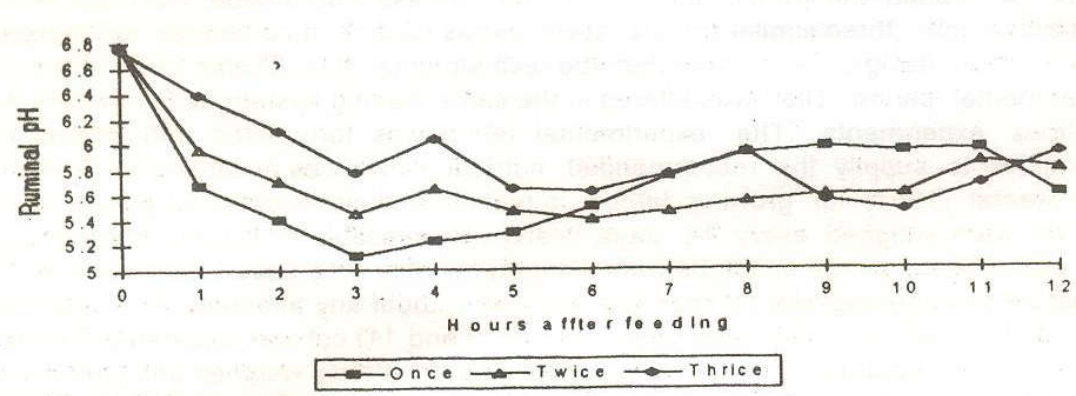

Figure. 1: Effect of feeding frequency on ruminal $\mathrm{pH}$. 
The decrease in pH values after $3 \mathrm{hr}$ post-feeding, for $1 X, 2 X$ and $3 X$ and at $5-6 \mathrm{hr}$ for $2 X$ and $3 X$ and at $9-10 \mathrm{hr}$ for $3 X$ feeding daily, coinsided with the feeding time. However, $\mathrm{pH}$ values fluctuated less for $2 \mathrm{X}$ and $3 \mathrm{X}$ feeding system. Similar trend was observed by Lardy ot al.,(1993); Taie (1993) and Baraghit ot al. (1995). They reported that values of $\mathrm{pH}$ were high before feeding then started to decline after $3-5 \mathrm{hr}$ post feeding. The effect of feeding frequency on VFA production in the rumen is shown in Fig. (2). Data of ruminal $\mathrm{pH}$ and VFA indicated that microbial activity was very low before feeding in all treatments.

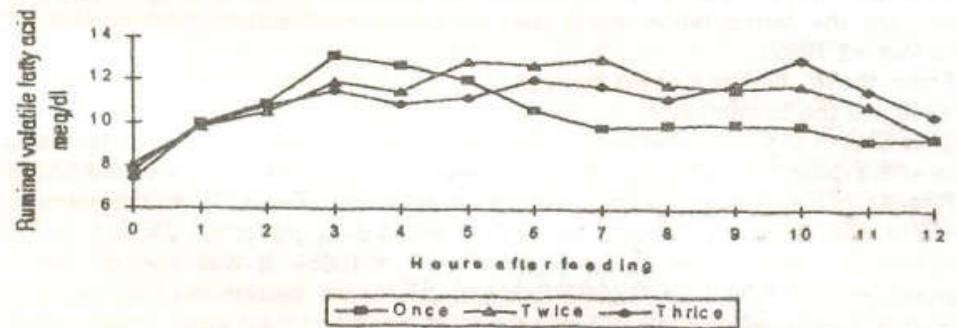

Figure 2: Effect of feeding frequency on ruminal volatil fatty acids.

Regardless of treatment effects a sharp increase in the VFA concentration was detected and reached a maximum at $3 \mathrm{~h}$ then steadily declined for $1 \mathrm{X}$, but continued to increase with less fluctuation for $2 X$ and $3 X$ daily feeding. The VFA concentration was negatively associated with $\mathrm{pH}$ value, which was expected. Similar finding was reported (Giacomini ot al., 1985; Burrin and Britton, 1986; Taie, 1993 and Baraghit ot al., 1995). They indicated that the progress of increasing ruminal total VFA concentration paralleled reduction in ruminal $\mathrm{pH}$. The energetic efficiency of rumen microbial production is related to the fermentable materials degraded to VFA by the rumen microorganisms during digestion (Hume, ot al., 1970; Walker and Nader, 1970: Mathison and Milligan, 1971) Ruminal ammonia concentrations at different times are presented in Fig. (3).

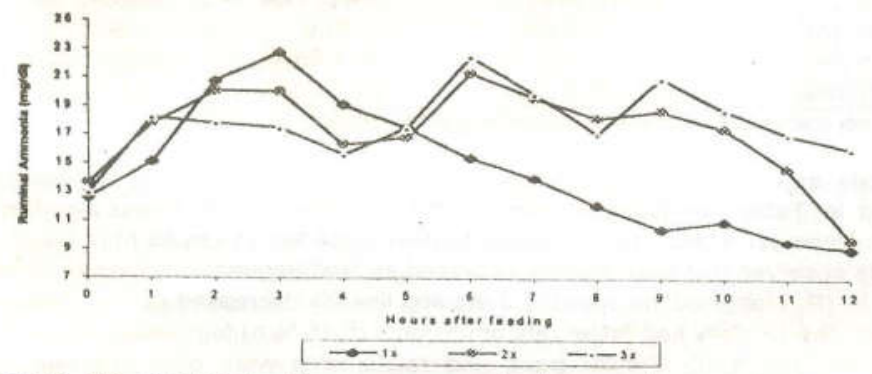

Figure3. Effect of feeding frequency on ruminal ammonia concentration. 
At 0 time all animals had the lowest ammonia concentration being $12.6,13.6$ and $12.95 \mathrm{mg} / \mathrm{dl}$ for $1 \mathrm{X}, 2 \mathrm{X}$ and $3 \mathrm{X}$ treatments. The highest value was $22.75 \mathrm{mg} / \mathrm{dl}$ for $1 X$ daily at $3 \mathrm{~h}$ post-feeding then began to decrease. However, it was 20 and $21 \mathrm{mg} / \mathrm{dl}$ for $2 X$ at 2 and $6 \mathrm{~h}$ post- feeding. The maximum values were 18.2, 22.5 and $21 \mathrm{mg} / \mathrm{dl}$ for $3 X$ daily at 1,6 and $9 \mathrm{~h}$ post-feeding. Church (1976) stated that normal level of rumen $\mathrm{NH}_{3}$ is of the order of 10 to $45 \mathrm{mg} / \mathrm{dl}$. Lardy et al.,(1993) reported that $\mathrm{NH}_{3}$ concentration reached the level of $28-40 \mathrm{mg} / \mathrm{dl}$ at $2 \mathrm{~h}$ post-feeding in weathers or steers fed rations containing different levels of $\mathrm{N}$. Barej et al.,(1976) recorded the highest $\mathrm{NH}_{3}$ concentration at $1 \mathrm{~h}$ post-feeding $(39.7 \mathrm{mg} / \mathrm{dl})$ in rumen fluid of sheep. Ammonia- $\mathrm{N}$ concentration is one of the important factors affecting rumen fermentation rate. However, the optimum concentration of $\mathrm{NH}_{3}-\mathrm{N}$ required to maximize the fermentation rate is quite variable in the literature (Mehrez of al., 1977; and Mehrez 1992)

From those finding it could be suggested that the higher the $\mathrm{NH}_{3}-\mathrm{N}$ concentration, the higher the fermentation rate. In the present study sheep fed $2 X$ and $3 X$ daily had higher $\mathrm{NH}_{3}-\mathrm{N}$ and produced more VFA (Fig. 2) which indicate the higher fermentation rate and explain the better digestibility (Table 2 ) in comparison to those fed $1 \mathrm{X}$ daily.

Results of the nitrogen balance (NB) are presented in Table (3). All the animals had positive NB. Nitrogen balance was $8.27,7.6$ and $6.46 \mathrm{~g} / \mathrm{d}$ for $3 X, 2 X$ and $1 X$ feeding respectively. Differences were significant $(P<0.05)$. It was noticed that both percentages of NB/NI or NB/ND followed the same pattern as NB. Values of NB reported herein were comparable to those reported by Ulyatt et al.,(1984) who found that NB was significantly greater with more frequent feeding. It was suggested that this was due to more efficient tissue utilization of nitrogen.

The increases in NB may have been due to the improvement of nutrient digestibilities which in turn could be attributed to one or more of the following explanations: (1) higher fermentation rate. (2) better ammonia concentration, and/or (3) longer retention time and slower flow rate out of the rumen, Table (4).

Table 3. Nitrogen balance as affected by feeding frequency.

\begin{tabular}{lccc}
\hline Item & \multicolumn{3}{c}{ Daily feeding frequency } \\
\cline { 2 - 4 } & once & twice & thrice \\
\hline $\mathrm{N}$-intake (Ni),g/h/d & $29.89 \pm 1.4$ & $30.03 \pm 0.1$ & $29.99+1.45$ \\
Fecal-N & $10.62 \pm 0.88 \mathrm{a}$ & $9.02 \pm 0.1 \mathrm{~b}$ & $9.21 \pm 0.35 \mathrm{~b}$ \\
Urinary-N & $12.81 \pm 1.3$ & $13.41 \pm 1.64$ & $12.6 \pm 2.33$ \\
$\mathrm{~N}$-digested (ND) & 19.27 & 21.0 & 20.78 \\
$\mathrm{~N}$-balance (NB) & $6.46 \pm 2.1 \mathrm{a}$ & $7.6 \pm 1.58 \mathrm{ab}$ & $8.22 \pm 1.13 \mathrm{~b}$ \\
$\mathrm{NB} \%$ of $\mathrm{N}$-intake & $21.61 \pm \mathrm{a}$ & $25.31 \pm \mathrm{b}$ & $27.11 \pm \mathrm{b}$ \\
\hline a, $\mathrm{b}$ values not sharing the same superscript within row are different $(\mathrm{P}<0.05)$.
\end{tabular}

Flow rate and retention time of rumen digesta as affected by feeding frequency are presented in Table (4). Digesta retention time in the rum (RRT) was significantly $(P<0.05)$ lower for sheep fed $1 \times(19.42 h)$ than those fed $2 X(24.88 h)$ or $3 X(31.25$ h). It was observed that RRT linearly increased as feed frequency increased. Digesta prate, $\% h \quad\left(R_{p}\right)$ followed the opposite trend and linearly decreased as feed frequency increased. The $1 X$ daily had faster rate of passage $(5.15 \% \mathrm{~h})$ followed by $2 \times(402 \%$ h) and $3 X(3.2 \% \mathrm{~h})$. Similar trend and relationship were observed with feed frequency by Robinson and Sniffen (1985) when lactating cows were fed $1 X, 2 X, 4 X$ 
and $8 X$ daily. Ehle and Stern (1984) stated that as feed intake increased rate of particulate passage increased. The longer retention time and slower passage rate could be a good explanation for the changes in digestibility (Table 2). As a result of increased digesta passage rate, time of exposure of feed particles to the digestive process was reduced. Another explanation was proposed by Staples ot al. (1984) that is time spent ruminating per unit of DM decreased with increasing the doses of DMI and increased mastication at lower dose of feed intakes would reduce particle size and increase surface area for enzymatic attack (Nangia and Garg, 1982). Owens and Goetsch (1988) reported that passage rate influenced fermentation pattern; this trend is clear in this study. Values of Rp were in the range reported by McCracken $\theta t$ al. (1993) and Baraghit et al. (1995).

Table 4: Rumen retention time, passage rate and fractional digestion of DM as affected by feeding frequency in sheep.

\begin{tabular}{|c|c|c|c|}
\hline \multirow[t]{2}{*}{ Item } & \multicolumn{3}{|c|}{ Daily feeding frequency } \\
\hline & once & twice & thrice \\
\hline Digesta RRT $h^{T}$ & $19.42+2.92 a$ & $24.88+2.71 b$ & $31.25 \pm 399 c$ \\
\hline DMRp, \% $h^{2}$ & $5.15 \pm 1.12 a$ & $4.02+0.65 b$ & $3.2+0.94 \mathrm{c}$ \\
\hline Rumen, $\%$ (units) $^{3}$ & $53.81 \mathrm{a}$ & $59.9 \mathrm{~b}$ & $65.21 \mathrm{c}$ \\
\hline Post ruminal \% (units) & $17.84 \mathrm{a}$ & $15.3 b$ & $11.28 \mathrm{c}$ \\
\hline Fraction DMD, rumen \% & $75.10 \mathrm{a}$ & $79.7 \mathrm{~b}$ & $85.25 \mathrm{c}$ \\
\hline Fraction DMD, post rumen $\%$ & $24.8 \div$ a & $20.3 b$ & $14.75 \mathrm{c}$ \\
\hline
\end{tabular}

1. Rumen retention time of DM, 2. Dry matter passage rate, $3 . \mathrm{h}$ situ DM digestion rate was $6.0 \mathrm{~h}^{-1}$

$a, b, c$ values not sharing the same superscript within the same row are differe $(P<0.05)$

The rate of digestion is required with the digesta rate of passage in order to calculate the fraction of total DM digested in the rumen (Waldo and Smith, 1972). Rate of digestion $\left(R_{d}\right)$ was estimated in this study (in situ) and found to be $6.0 \% \mathrm{~h}^{-1}$ Data in Table (4) indicated that DM digested within the rumen for experimental animals were $53.81,59.9$ and 65.21 units for $1 X, 2 X$ and $3 X$ daily respectively. The DMD post ruminaly followed the opposite trend being low for $3 X$ daily and high for $1 X$ daily. Values were $17.84,15.3$, and 11.28 units for the same respective treatments. Baraghit et al. (1995) reached similar values when DMI was changed in sheep feeding from 100 to $70 \%$. The same trend was obtained when ruminal fraction DMD was calculated as percentage which tended to increase as feed frequency increased. Values were $75.1 \%, 79.7 \%$ and $85.25 \%$ for the same respective treatments. The respective percentage of DM digested post ruminaly were $24.89,20.3$ and $14.75 \%$. Ganev et al. (1979) and Weakly et al. (1983) reported that the faster rate of digestion may be due to shift in microbial type in response to chemical or physical characteristics of the ruminal medium.

The effect of feeding frequency on average daily gain (ADG) and feed efficiency (FE) of sheep during 150 day period are presented in Table (5). Average daily gain was 165, 175 and $181 \mathrm{~g} / \mathrm{d}$ for $1 \mathrm{X}, 2 \mathrm{X}$ and $3 \mathrm{X}$. Differences were statistically significant $(P$ $<0.05$ ). The $2 X$ and $3 X$ feed frequency tended to improve ADG by 4.2 and $10.24 \%$ over the $1 X$ daily. Feed efficiency $(\mathrm{kg} \mathrm{DM} / \mathrm{kg}$ gain) was significantly higher $(P<0.05)$ for $2 X$ and $3 X$ than $1 X$. Gibson (1981) indicated that increasing feeding frequency 
from one or two meals per day to four meals improved ADG and efficiency of food utilization with some incidence of further improvement at higher feeding frequency

Table 5. Effect of feeding frequency on performance of lambs.

\begin{tabular}{lccc}
\hline Item & \multicolumn{3}{c}{ Daily feeding frequency } \\
\cline { 2 - 4 } & once & twice & thrice \\
\hline IBW, kg (Initial body weight). & $30.25 \pm 2.0$ & $31+2.0$ & $32.26+1$ \\
FBW, kg (Final body weight). & $55 \pm 1.2$ & $57.25 \pm 1.8$ & $59.5+2.0$ \\
DMI, g/d (Dry matter intake). & 1354 & 1359 & 1358 \\
WI, L/d (Water intake). & 4.0 & 5.2 & 5.6 \\
Experimental period & 150 & 150 & 150 \\
LWG, g/d (live weight gain). & $165 \pm 10.66 \mathrm{a}$ & $175.0 \pm 1.2 \mathrm{~b}$ & $181.9 \pm 11.4 \mathrm{~b}$ \\
Improvement, \% & - & 4.2 & 10.24 \\
FE, kg DM/kg gain(Feed efficiency) & $8.21 \mathrm{a}$ & $7.51 \mathrm{~b}$ & $7.47 \mathrm{~b}$ \\
\hline a,
\end{tabular}

व, values not sharing the same superscript within row are different $(P<0.05)$.

Mean daily voluntary water intake was insignificantly increased by feeding frequency (Table 5). However, sheep fed once daily tended to consume least (4.0 $L / d)$ and those fed 3X the most $(5.6 \mathrm{~L} / \mathrm{d})$. Nocek and Braund (1985) stated that cows fed $4 X$ daily frequency tended more evently to distribute DM and water consumption over the daily feeding cycle, which in turn is combined with the highest dilution rate, compared with $1 X$ and $2 X$. This may result in more consistent supply of nutrients for microbes during the $24 \mathrm{~h}$ Harrison et al. (1975); Russell and Hespell (1981) indicated that increased ruminal dilution rate is associated with increased delivery of microbial protein to the lower gut. This is a result of greater bacterial growth yields at high growth rate.

Data presented in Table (6) showed the effect of feeding frequency on carcass characteristics of sheep.

Table 6. Carcass traits of sheep as affected by feeding frequency.

\begin{tabular}{lccc}
\hline Item & \multicolumn{3}{c}{ Daily feeding frequency } \\
\cline { 2 - 4 } & once & twice & thrice \\
\hline Slaughter wt. after fasting, $\mathrm{kg}$ & 55.0 & 57.25 & 59.5 \\
Empty body weight, $\mathrm{kg}$ & 48.0 & 50.1 & 52.11 \\
Hot carcass weight, $\mathrm{kg}$ (I) & 26.82 & 28.29 & 30.62 \\
Hot carcass weight, $\mathrm{kg}$ (II) & 24.65 & 25.55 & 27.93 \\
Dressing percentage, \% & & & \\
Based on fasting weight (I) & 48.95 & 49.4 & 51.5 \\
Based on fasting weight (II) & 44.82 & 44.63 & 46.94 \\
Based on empty weight (I) & 56.1 & 56.5 & 58.76 \\
Based on empty weight (II) & 51.35 & 52.0 & 53.6 \\
Dissecting the best ribs & & & \\
Lean \% (L) & 51.71 & 54.53 & 52.92 \\
Fat \% (F) & 25.11 & 25.1 & 27.5 \\
Bone \% (B) & 23.11 & 20.37 & 19.6 \\
L / F ratio & 2.1 & 2.17 & 1.92 \\
L/ B ratio & 2.23 & 2.68 & 2.7 \\
\hline
\end{tabular}

(I): Carcass with offals $\quad$ (II) : Carcass without offals 
The $3 X$ feeding frequency tended to slightly increase the hot carcass weight, but the differences were not significant. This was mainly due to the higher pre-slaughter weight for sheep fed $3 X$ as compared with $1 X$. Dressing percentage expressed as hot carcass without or with offals (liver, heart, kidneys and tests) based on pre-slaughter liveweight or empty body weight were not affected by the different feeding frequency. The value of percentage of lean, fat and bone are shown in Table (6).

There was no significant differences between the three tested regimen. Carcass chemical analysis (Table 7) indicated that as feed frequency increased, the DM\% non significantly decreased. It was documented that as lean percentage increased moisture content increased and $D M$ decreased. It was obvious that $2 X$ had more protein ( 75.86 vs 73.83 for $1 X$ ) and less fat (20.72 vs 22.55 for $1 X$ ).

Table 7: Chemical composition of eye muscle of sheep as affected by the feed regimen.

\begin{tabular}{lccc}
\hline Item & \multicolumn{3}{c}{ Daily feeding frequency } \\
\cline { 2 - 4 } & once & twice & thrice \\
\hline DM & $28.78 \pm 1.63$ & $26.09 \pm 0.64$ & $24.62 \pm 1.63$ \\
CP & $73.83 \pm 1.73$ & $75.86 \pm 1.05$ & $74.73 \pm 1.29$ \\
EE & $22.55 \pm 1.63$ & $20.72 \pm 0.92$ & $21.39 \pm 1.63$ \\
Ash & $3.67 \pm 0.1$ & $3.26 \pm 0.18$ & $3.89 \pm 0.63$ \\
\hline
\end{tabular}

It could be concluded that $2 X$ and $3 X$ feed frequency tended to improve sheep performance. Twice feeding daily, however, seems to be reasonable when the labor costs are considered.

\section{REFERENCES}

Al-Rabbat, M. F., R.L. Baldwin and W. C. Weir, 1971. In vitro nitrogen-tracer technique for some kinetic measures of ruminal ammonia. J. Dairy Sci., 54:150.

A. O. A. C., 1980. Association of Official Agricultural Chemists. Official method for analysis. 13th ed. Washington, D. C.

Baldwin, R. L. and S. C. Denham, 1979. Quantitative and dynamic aspects of nitrogen metabolism in the rumen: A modelling analysis. J. Animal. Sci. 49:1631.

Baraghit, G. A., B. M. Ahmed, A. F. Shehata and H. T. Taie, 1995. Effect of clover intakes by sheep and goats on digestion kinetics. Proc. 5 th Sci, Conf. Animal Nutrition. 1:153, Ismailia.

Barej, W., B. Krasha, G. Kulasek and M. Szczygiel, 1976. Physiological evaluation of urea concentration in feeds for ruminants. 4. Effect of composition of the diets and pelleting the urea concentrates on nitrogen metabolites in the rumen and blood of sheep. Nut. Abs. Rev.46:912

Burrin, D.G. and R.A. Britton, 1986. Response to monensin in cattle during sub acidosis. J. Anim. Sci. 63:888.

Burt, A. W. A. and C. R. Dunton, 1967. Effect of frequency of feeding upon food utilization by ruminants. Proc. Nut. Soc. 26:181.

Church, D. C., 1976. Digestive Physiology and Nutrition of Ruminants. $V$ (1). Digestive Physiology, 2nd ed. O and B. Book, Corvallis, Oregon. 
Ehle, F. R. and M. D. Stern, 1984. Physical and chemical variables influencing particle passage and size reduction. In: Modeling ruminant digestion and metabolism. 2nd Internal Workshop. Univ. Cal. Davis. 27.

Ganev, G., E. R. Ørskov and R. Smart, 1979. The effect of roughage or concentrate feeding and rumen retention time on total degradation of protein in the rumen. $J$. Agr. Sci. (Camb.) 93:651.

Ghoneim, A. and M. A. Raafat., 1957. Mutton production from Egyptian sheep. II. Growth studies from weaing up to one year old. Bul. No. 113. Fac. Agric. Cairo Univ. Egypt.

Giacomini, D. G., J. H. Clark and J. L. Vicini., 1985. Effect of sequence of feeding on ruminal fermentation, milk yield and milk composition. J. Dairy Sci. 68 (suppl.1). 1342

Gibson, J.P., 1981. The effects of feeding frequency on the growth and efficiency of food utilization of ruminants: an analysis of published results. Anim. Prod. 32 275.

Gill, J. L., 1978. Design and analysis of experiments in the animal and medical sciences. The lowa State Univ. Press, Ames, lowa, USA.

Harrison, D. D., D.E. Beever, D. J. Thomson and D. G. Osbourn, 1975. Manipulation of rumen fermentation in sheep by increasing the rate of flow of water from the rumen. J. Agric. Sci. (Camb.) 85:39.

Honing, Y. V. D., G. A. Bangama, G. W. Homan, R. Terluin, B. Thieler and J. E. Voigt, 1976. Effect of methane production and energy balance of increased feeding frequency of concentrates to lactating cows. Page 77 in Proc. 7 th Eur. Assoc. Anim. Prod. Symp. Vichy, France.

Hume, I. D., R. J. Moir and M. Somers, 1970. Synthesis of microbial protein in the rumen. 1. Influence of the level of nitrogen intake. Aust. J. Agr. Res. 21:283.

Jensen, K. and J. Walstrup., 1977. Effect of feeding Frequency on fermentation pattern and microbial activity in the bovine rumen. Acta Vet. Scand. 18:108.

Johnson, R. R., 1976. Influence of carbohydrate solubility on non protein nitrogen utilization in the ruminant. J. Anim. Sci. 43. 184.

Lardy, G. P., G. E. Catlett, M. S. Kerley and J. A. Patreson, 1993. Determination of the ruminal escape value and duodenal amino acid flow of rapseed meal. J. Anim. Sci. 71:3096.

Markham, R. A., 1942. Steam distilation apparatus for microkjeldahl analysis. Biochem. J. 36:790.

Mathison, G. W. and L. P. Milligan, 1971. Nitrogen metabolism in sheep. Br. J. Nutr. 25:351.

Maynard, L. A., J. K. Loosli, J. K., H. S. Hintz and R. G. Warner, 1979. Animal Nutrition. McGraw-hill Boock Co. Inc. N. Y.

McCracken, B.A., M. B. Judkins, L. J. Krysl, D. W. Holcombe and K. K. Park, 1993. Supplemental methionine and time of supplementation effects on ruminal fermentation, digesta kinetics and in situ dry matter and neutral detergant fiber disappearance in cattle. J. Anim. Sci. 71:1932.

Mehrez, A. Z., 1992. Influnce of roughage: concentrate ratio on nitrogen requirements of rumin microbes for maximal rate of fermintation. Page 234, Conf. Manipulation of rumen microorganismis. Alex. Egypt.

Mehrez, A. Z. and E. R., Ørskov, 1977. A study of the artificial fiber bag technique for determining the digestibility of feeds in the rumen. J. Agric. Sci. (Camb.) 88:645. 
Mehrez, A. Z., E.R. Ørskov and I. McDonald, 1977. Rates of rumen fermentation in relation to ammonia concentration. Brit. J. Nutr., 38:437.

Nangia, O. P. and S. L. Garg, 1982. Ingestive behaviour and to correlate blood metabolites at specific items with feed intake pattern in buffalo calves. Indian J. Dairy Sci. 35:526.

Nocek, J. E., 1987. The influence of feeding frequency on ruminal parameters and production response in dairy cattle. Prof. Anim. Sci 2:69.

Nocek, J. E., 1992. Feeding sequence and strategy effect on ruminal environment and production performance in first lactation cows. J. Dairy Sci. 75:3100,

Nocek, J. E. and D. G. Braund., 1985. Effect of feeding frequency on durinal dry matter and water consumption, liquid dilution rate and milk yield in first lactation. J. Dairy Sci. 68:2238

NRC. 1975. National Research Council. Nutrient Requirements of Domestic Animals. "Nutrient Requirements of Sheep". Natl. Acad. Sci., Washington, DC

Owens, F. N. and A. L. Goestsch, 1988. Ruminal Fermentation In:D. C. Church (ED). The Ruminant Animals: Digestive Physiology and Nutrition. PP 145.

Robinson, P. H. and C. J. Sniffen., 1985. Forestomach and whole tract digestibility for lactating dairy cows as influenced by feeding frequency. J. Dairy Sci. 68:857.

Russell, J. B. and R. B. Hespell, 1981. Microbial rumen fermentation. J. Dairy Sci. $64: 1153$

Smith, N. E., G. R. Ufford, C. E. Coppock and W. G. Merrill., 1978. Complete rationgroup feeding systems for dry and lactating dairy cows. J. Anim. Sci. 61:584

Stanley, R. W. and K. Morita, 1967. Effect of frequency and method of feeding on performance of lactating dairy cattle. J. Dairy Sci. 50:585.

Staples, C. R. R. L. Fernando, G. C. Fahmy, Jr. L. L. Berger and E. H. Jaster., 1984. Effect of intake of a mixed diet by dairy steers on digestion events. J. Dairy Sci. 67:995

Taie, H. T., 1993. Digestibility and rumen fermentation as affected by urea-treated corn cobs in comparison to berseem hay in fistulated sheep. Minofiya J. Agric. Res. 14:239.

Ulyatt, M. J., G. C. Waghorn, A. John, C. S. W. Reid and J. Monro., 1984. Effect of intake and feeding frequency on feeding behaviour and quantitative aspects of digestion in sheep fed chaffed lucerne hay. J. Agric. Sci., (Camb.) 102:645.

Waldo, D. R. and L. W. Smith, 1972. Model of cellulose disappearance from the rumen. J. Dairy Sci. 55: 125.

Walker, R. A and C. J. Nader, 1970. Rumen microbial protein synthesis in relation to energy supply: durinal variation. Asut J. Agr. Res. 21:747.

Warner, A. C. I., 1964. Production of volatile fatty acids in the rumen. Methods of measurements. Nutr. Abst. Rev. 34:339.

Weakley, D. C., M. D. Stern and L. D. Satter, 1993. Factors affecting Disappearance of feed stuffs from bags suspended in the rumen. J. Anim. Sci. 56:493.

William, C. H., Darid D. J. and Ishmaa, O 1962. The determination of chromic oxide in feces samples by atomic absorption spectrophotometry. J. Agric. Sci. (camb) $59: 381$ 
تأتير تكرار التفذية على ميكاتيكية الهضم والأداء وصفات الذبيحة في الأغنام

$$
\begin{aligned}
& \text { حدى توفيت طايع } \\
& \text { قسم الانتاج الديو انى -كليه زر اعة شبين الكوم ـ جامعة المنوفية }
\end{aligned}
$$

أجريت عده تجارب لدراسة تاثير تكر ار ثقديم الغذاء على كل من تخمر ات الكرش ، القدرة الهضمبهة،

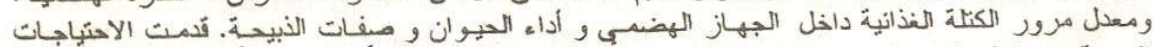

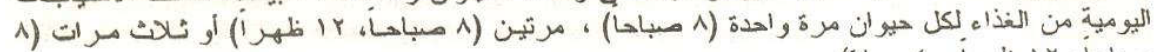

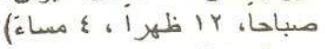
التجربة الاولى استخدم r ذكور خر اف أوسيمى بالغة النمو وذلك لغرض قياس القدرة الهضمية والميزان

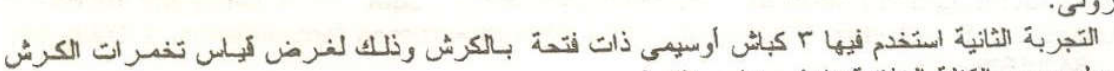
الازوتى.

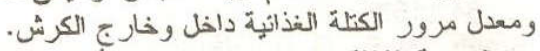

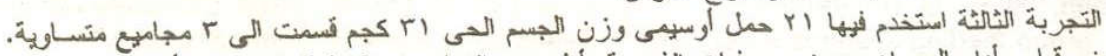

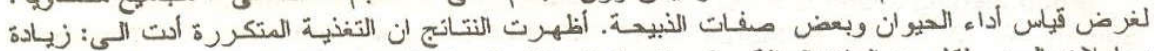

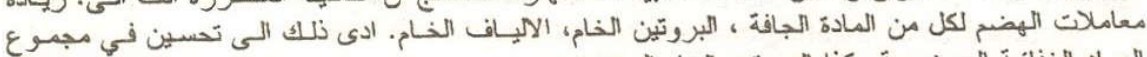

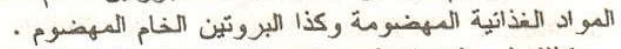

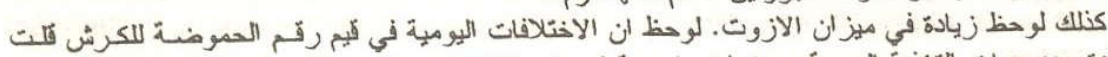

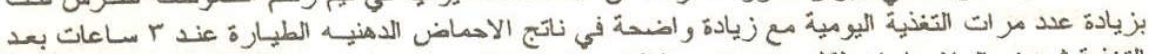

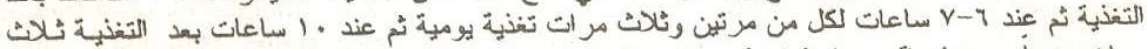

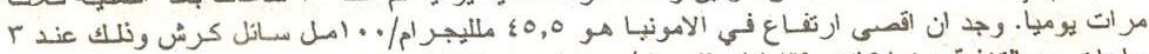

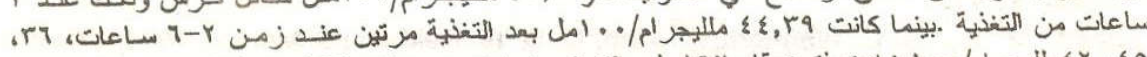

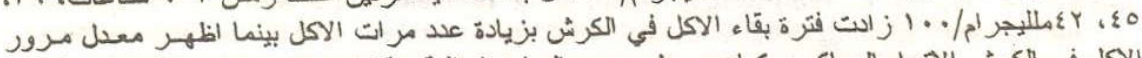

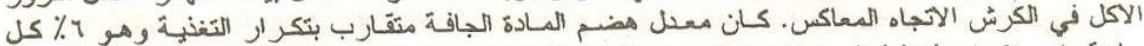

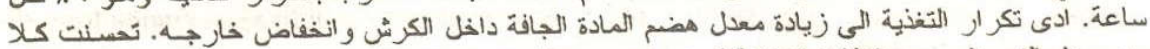

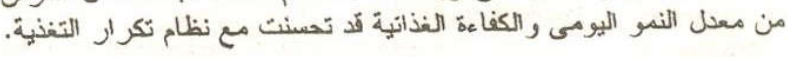

